\title{
CHOICE OF OPERATION IN CHRONIC ARTHRITIS OF THE HIP*
}

\author{
BY
}

\author{
W. D. COLTART \\ St. Bartholomew's Hospital, London
}

(RECEIVED FOR PUBLICATION JULY 24, 1953)

In spite of advances in our understanding of rheumatism, the more expert handling of injuries, and the improved care of children with hip disabilities, surgery continues to play a large part in the treatment of chronic arthritis of the hip.

With the patient before him, the surgeon must decide whether surgery is indicated at all, and, if it is, what to advise. It is this latter choice, between the various operations available, which will be considered here. The clinical factors cannot be tabulated and cross-indexed so that the right operation is chosen by a kind of Hollerith system; many different surgical procedures have been described for the treatment of chronic arthritis of the hip, there is no scientific method of selection, and here the surgeon must exercise the art of medicine if he can!

In 1859, Fock of Magdeburg, performed the first operation on the hip for osteo-arthritis (Fock, 1861). He carried out a radical subtrochanteric resection, implanting the stump of the upper end of the femur in the acetabulum. The patient was a man of 49 , and the result was relief of pain, but with a very unstable hip. Although Verneuil had suggested the interposition of soft tissue in order to produce a moveable joint, without wide resection, it was not until 1906 that Hoffa published the results of arthroplasty in five cases of ankylosed hip-joints. In spite of a good deal of pioneering work by Murphy (1905) and other American surgeons, the results of arthroplasty for osteo-arthritis of the hip were poor, and resection remained the only operative procedure available. In 1908, Albee carried out an arthrodesis of the hip for osteo-arthritis (Albee, 1908). Because of widespread failure to secure good bony ankylosis the operation did not become popular; this failure was emphasized at a British Orthopaedic Association Meeting in 1920 by Platt and others (1922), and the accounts of this meeting and of a similar discussion held by the Section of Orthopaedics of the British Medical Association in 1923 make gloomy reading,

\footnotetext{
* Read to the Heberden Society on December 13, 1952.
}

although Elmslie (1923) pointed out that failure in excision of the head of the femur was very often $\vec{N}$ the result of bad after-treatment, and that arthro- $\stackrel{N}{\omega}$ desis, when it succeeded in producing a bony $\vec{t}$ ankylosis of the hip, was a very good operation.

Albee (1921) changed his technique of arthrodesis 은 by adding an extra-articular graft to the intra- articular removal of cartilage, and vastly improved $\mathscr{D}$ the chances of obtaining a firmly ankylosed joint. Arthrodesis was carried a stage further by WatsonJones (1935) when he augmented intra-articular $\underset{\mathbb{D}}{ }$ arthrodesis by firm fixation with a three-flanged stainless steel nail, driven up through the neck of the femur into the ilium.

In the U.S.A. the surgical struggle to obtain mobile, painless, and reasonably stable hip in chronic arthritis had continued. Smith-Petersen introduced his operation of acetabuloplasty in 1936. The results were not startlingly good, and the $\mathbb{Q}$ particular significance of the operation lay, first, in $\overrightarrow{\vec{A}}$ the realization that wide excision of the capsule of $\frac{0}{3}$ the hip was an important factor in the relief of pain, and, secondly, in a new operative approach to the joint. This approach gave a far wider exposure than his previous method, and by reflecting the psoas muscle inwards enabled a good view of the acetabular $\overline{0}$ roof and pelvic surface: it was this new exposure which materially assisted him in his work on vital- $\delta$ lium cup arthroplasty. He had been experimenting with materials to form a mould to interpose between 음 the reshaped acetabulum and head of the femur since $D$ 1925 , and in 1939 he wrote:

By the introduction of an inert mould around which $N$ nature can do her repair work two congruous surfaces mechanically suitable for joint function are created and $\mathcal{N}$ fibrous tissue formation is confined to the periarticular $N_{\mathrm{W}}$ region forming a joint capsule.

He had tried glass, Pyrex, Viscaloid, and Bakelite 0

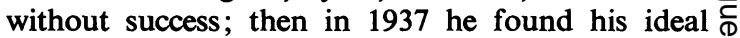
material in the new alloy Vitallium. Although he $\stackrel{\infty}{+}$ first described mould arthroplasty in 1939, the events 0 

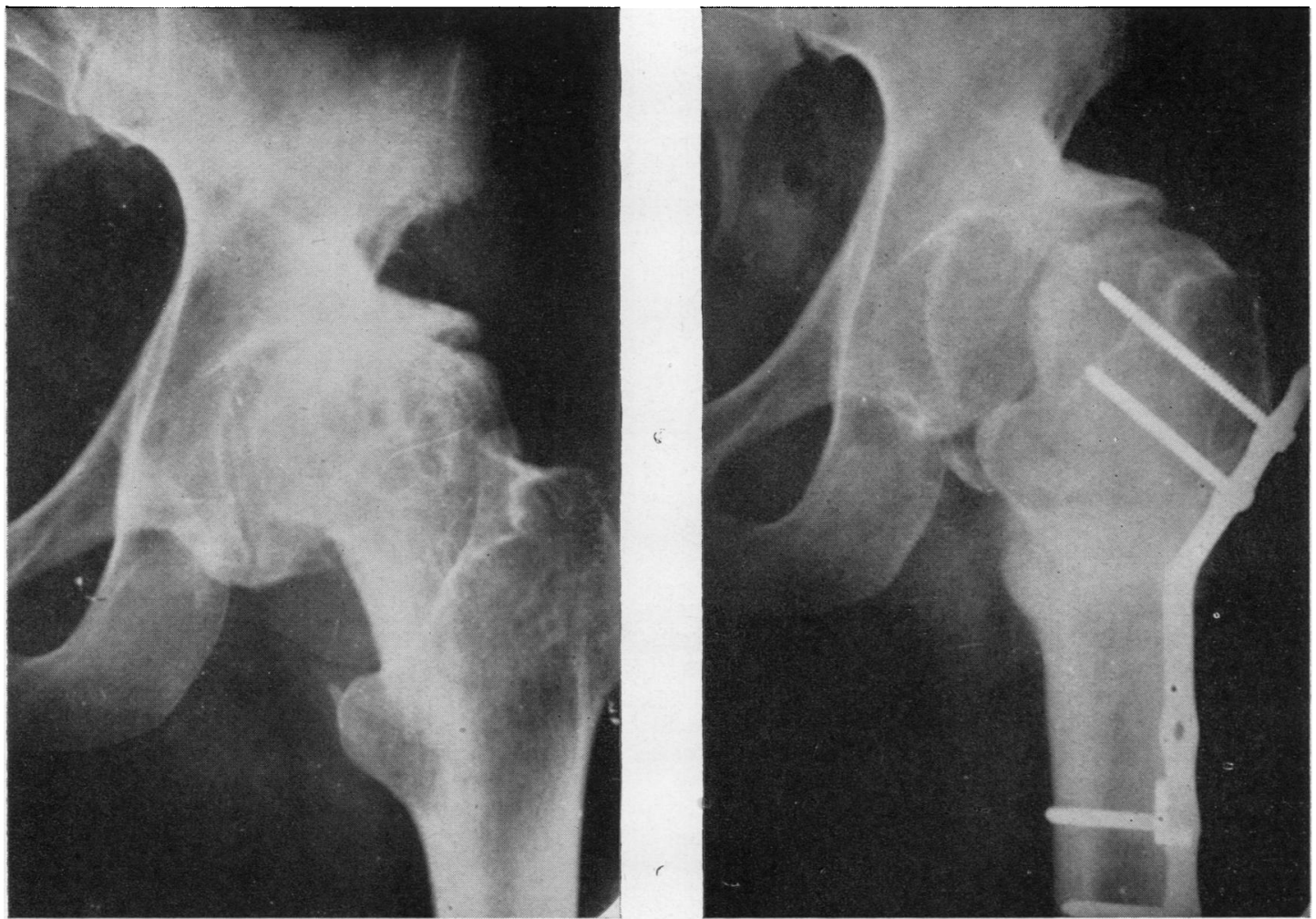

Fig. 1.-Batchelor's excision osteotomy.

of war delayed its application to chronic arthritis in Great Britain.

In a discussion on the treatment of unilateral osteo-arthritis of the hip by the Orthopaedic Section of the Royal Society of Medicine, Girdlestone (1945) reported that he had returned to excision of the head of the femur, but by doing a wider excision of the whole head and neck and by more careful attention to after-treatment he was able to report fourteen excellent results in 25 patients. On the same occasion McFarland (1945) described the use of an intertrochanteric displacement osteotomy devised by McMurray, Watson-Jones (1945) produced an impressive series of arthrodeses, and Pridie (1945) was able to report a few successful cases treated by vitallium mould arthroplasty.

Although not mentioned in the discussion, Brittain of Norwich had, in 1942, introduced his method of ischiofemoral arthrodesis, and Tavernier and Truchet (1942) had suggested denervation of the hip. At about this time also Batchelor (1945) had modified Girdlestone's excision operation by adding a Schanz type of osteotomy (Fig. 1), which resulted in considerable improvement in stability of the excised hip, and was of particular value in the bilateral ankylosis of spondylitis rhizomelique. Finally, Judet and Judet (1950) published their method of arthroplasty with an artificial femoral head made from an acrylic resin.

After nearly one hundred years the orthopaedic surgeon can feel confident that he has a reasonable chance of producing a firm, painless ankylosis of one hip, a mobile, stable, and relatively pain-free joint on one or both sides, or relief of pain for a short period by a less serious operation. These effects can be achieved respectively by arthrodesis, by some form of reconstruction of the joint, or by denervation.

Some of the technical points in these operations and their after-care, which might influence our choice, may now be considered.

\section{Arthrodesis}

The hip joint is exposed and opened: articular cartilage is removed, and part of the cavity packed with cancellous bone from the iliac crest: a large Smith-Petersen type of 
nail is driven in to hold the head of the femur firmly impacted in the acetabulum. This second step may be undertaken at another operation, 3 or 4 weeks after the first. A plaster hip spica is then applied, which at first includes the knee and foot, but leaves the unaffected hip free. After 4 to 6 weeks, the knee is freed to allow exercises, and the patient begins to get about on crutches. To be certain of a secure bony ankylosis it is usually necessary to maintain the plaster for at least 12 weeks.

At one time it was suggested that nail-fixation alone was sufficient and that opening the joint was not necessary, but this far simpler method has proved unsuccessful in practice, because the ankylosis produced is not reliable and because it may not be possible to correct deformity without opening the joint.

\section{Reconstruction}

Vitallium Mould Arthroplasty.-It is necessary to reshape the head of the femur and the acetabulum. This may prove technically difficult. The reshaped head may be too small and loose in the cup, and the shape of the mould is such that it may very easily become seized-up by new bone formation at the rim of the acetabulum. Smith-Petersen says that it may be necessary to "review the hip", by which he means repeat the operation, and some observers have been impressed by the number of his cases which have in fact been reviewed. Post-operative treatment consists of 4 weeks'-traction, 4 weeks' mobilizing exercises in bed, 4 weeks' non-weight bearing on crutches, and then about 8 weeks of progressive weightbearing exercises.

Acrylic Head Prosthesis.-After removal of part of the head of the femur, an acrylic resin head is attached firmly by its stem, which is driven down the neck of the femur, to the cortex just below the great trochanter. The stem is now reinforced by a stainless steel core. At one time it was considered unnecessary to reshape the acetabulum, and this was a decided advantage in time and trouble over the vitallium mould, but further experience suggests that a good mechanical fit is worth the extra time involved, and now the acetabulum is usually deepened and smoothed out. A bad fit, especially if the acetabular roof is sclerotic, will fail to relieve pain (Fig. 2). Post-operative treatment is on the same lines, but shorter, than in the Smith-Petersen operation-2 weeks' traction, 2 weeks' mobilizing in bed, and weight-bearing on crutches 6 weeks after operation.

Batchelor's Operation.-This is carried out in two stages: first, the head and neck of the femur are cleanly excised close to the great trochanter; at the second stage an osteotomy is performed just below the lesser trochanter. The upper fragment is adducted, the lower fragment abducted, and they are then secured with an angled stainless steel plate. It is better to aim at a small angle, just enough to provide a weight-bearing surface for the pelvis. The interval between the two stages is 3 weeks, and traction is then necessary for 8 weeks, followed by 3 to 4 weeks of non-weight bearing exercises.

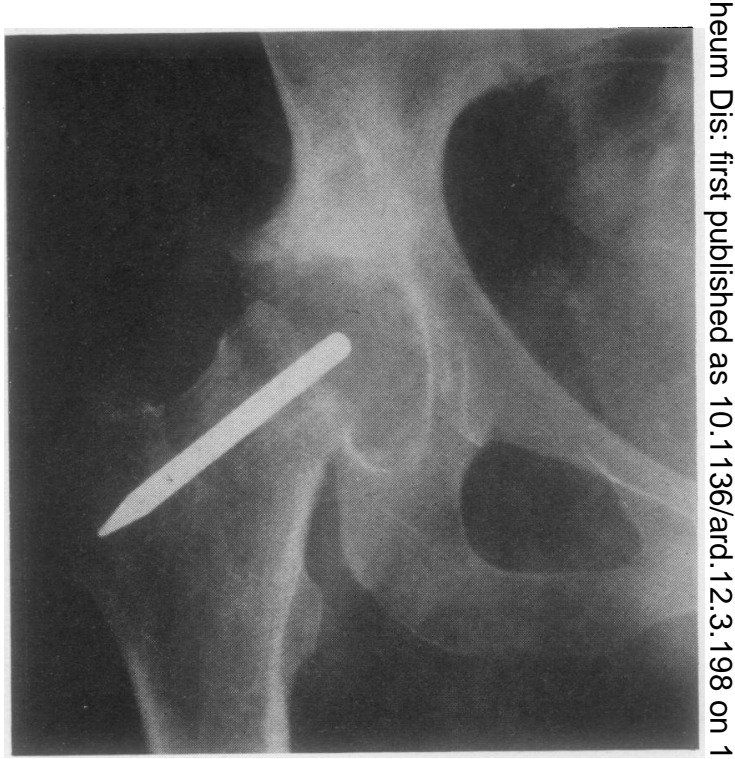

Fig. 2:-Judet reconstruction. Incomplete removal of sclerotic $\Omega$ acetabular bone. Pain not relieved by operation.

\section{Denervation}

The obturator nerve can be exposed where it emerges through its foramen by an incision in the groin and dipise sion of the pectineus muscle (Kaplan, 1948). The nesyew trunk can be avulsed by traction, and probably all काie anterior branches to the hip joint are removed by this method. Even in bilateral cases, an abdominal incision is unnecessary and adds to the seriousness of the procedure $\bar{\square}$ For the second part of Tavernier's operation, the patient is turned into the prone position, and through an incision in the buttock the branch to the hip joint from the nerve to quadratus femoris is divided. The denervation opera- 3 tion tends to fail because it is impossible to divide all the nerves to the hip, because painful symptoms tend to recur, and because deformity of the hip cannot be corrected.

\section{Discussion}

Arthrodesis and reconstruction are formidable operations, but under proper conditions fatal o? serious complications are few.

The success of an arthrodesis, if chosen properly? depends in the main on whether bony ankylosis results. Watson-Jones (1945), in reporting favourably. on 185 arthrodeses for osteo-arthritis of the hiper comments that:

(i) the severity of the operation is now not an obstacles

(ii) the desirable stiffness of the hip is compensated by pelvic movement,

(iii) the stiff knee can be avoided by careful aftero treatment,

(iv) low backache does not occur unless it was there? before the operation. 
TABLE

RESULTS OF SMITH-PETERSEN VITALLIUM MOULD ARTHROPLASTIES (AFTER LAW, 1948)

\begin{tabular}{|c|c|c|c|c|c|c|}
\hline \multirow{2}{*}{ Length of Time } & \multirow{2}{*}{ Type of Chronic Arthritis } & \multirow{2}{*}{ No. of Operations } & \multicolumn{2}{|c|}{ Satisfactory to Patient } & \multicolumn{2}{|c|}{ Satisfactory to Surgeor } \\
\hline & & & Yes & No & Yes & No \\
\hline \multirow[t]{2}{*}{ More than 2 years } & $\begin{array}{l}\text { Osteo-arthritis } \\
\text { Rheumatoid arthritis } \\
\text { Other forms }\end{array}$ & $\begin{array}{r}7 \\
12 \\
59\end{array}$ & $\begin{array}{r}7 \\
12 \\
52\end{array}$ & $\overline{7}$ & $\begin{array}{r}7 \\
10 \\
46\end{array}$ & $\frac{-}{2}$ \\
\hline & Total & 78 & 71 & 7 & 63 & 15 \\
\hline More than 4 years & All Types & 33 & 29 & 4 & 26 & 7 \\
\hline
\end{tabular}

Before the days of intra- and extra-articular fusion and fixation with a nail, ankylosis could only be relied on in 40 per cent. of cases, but nowadays we can secure bony ankylosis in 90 per cent. of osteoarthritic hips. It is, of course, in the treatment of osteo-arthritis that arthrodesis reaches its main significance.

In assessing the results of reconstruction operations, we wish to know not only whether the immediate result is satisfactory to the patient and surgeon, but whether it lasts over the ensuing years. The Table shows some results of the Smith-Petersen operation, summarized from a report by Law (1948). These suggest that the operation does last, but we may feel that 5 years is a short period, and it is not possible to tell from this report how many of the hips had needed revision operations. The published results of Judet and Judet (1952) show 36 per cent. bad or poor results, 47 per cent. good, and 17 per cent. excellent. From the figures so far we cannot tell how long the good results last, but at least some remained good or excellent for 5 years, and their criteria of success are very exacting. Most orthopaedic surgeons would agree that at the moment this operation is the more popular-not because it is the latest, but because it is on the whole easier, aftertreatment is shorter, the hips are more stable, and the patient walks better. The Smith-Petersen operation carries with it the possibility that revision may have to be undertaken before the final result is achieved, nevertheless, the reconstructed hip can be revised, whereas Judet says nothing about the possibilities of revision after his operation, and such a procedure is obviously difficult. We cannot yet say that one operation is definitely better than the other for reconstruction of the hip. We do not know how long either will last. Perhaps some new operation will arise, and it will be interesting to reconsider the situation in 10 years' time. Batchelor has not yet reported on a large series of cases treated by his method of reconstruction, but in 1948, he reported four bilateral cases of ankylosing spondylitis and six of unilateral osteo-arthritis, all with stable hips and walking painlessly without sticks; some of these cases had been reviewed nearly 10 years after operation.

It is possible to summarize from Mulder (1948) the results obtained by several surgeons in denervation of the hip. The combined reports of Tavernier (1944), Tavernier and Godinot (1945), Donkersloot (1947), Obletz and others (1949), Kaplan (1948), and Mulder himself, show 82 good or satisfactory results, and 87 which were only fair or failed altogether. None of these cases had been followed for more than 2 years, and some had relapsed before that. Denervation is not popular because it does not last, and pain recurs, and it is not successful in patients with severe hip disability even if they are unfit for a more drastic operation. For the patient with a mobile hip, no deformity, and pain localized in the groin, avulsion of the femoral nerve may be of value. He must clearly understand that the operation may not succeed, or that relief may only be temporary: but the operation is a comparatively slight one, and is all over in 2 or 3 weeks. It may be usefully combined with a major operation on the other hip.

The reported results available to us seem to confirm that we can offer the patient a reasonable chance of success with Arthrodesis, and with one or other form of Reconstruction, or temporary relief in mild cases with Denervation.

\section{Factors Influencing Choice of Operation}

In making the choice of operation there are four important features of each case to be considered:

(1) Whether the arthritis is bilateral,

(2) The physique, general condition, and attitude towards operation of the patient,

(3) Whether from the economic and social viewpoint movement or stability at the hip is more important,

(4) The type of arthritis. 
(1) Bilateral Arthritis.-Here we meet with three possible situations:

(a) One hip is much less affected than the other,

(b) Both hips are severely affected and painful,

(c) Both hips are rigid, and perhaps painful.

(a) We must not do an arthrodesis of the more severe hip, and must choose one of the reconstruction operations. The choice will be influenced by the type of arthritis, and this will be discussed later. The less affected hip may settle completely with rest in bed, or a denervation alone may suffice to stave off a reconstruction operation for some time. However, if there is a marked deformity of the less painful hip, it will be advisable to do a reconstruction to avoid strain on the first reconstructed hip.

(b) When both hips are severely affected and painful, we can do a reconstruction operation on each with a few weeks' interval between. Again, the type of arthritis will settle which reconstruction we choose.

(c) Severe rigidity of both hips may be so disabling that bilateral reconstruction operations are indicated, even though pain is not a marked feature. More often than not we are dealing with ankylosing spondylitis or rheumatoid arthritis. For reasons which will be discussed later, there is a preference for the Batchelor reconstruction in ankylosing spondylitis, and for the vitallium mould arthroplasty in rheumatoid arthritis.

(2) Physique, General Condition, and Attitude towards Operation of the Patient.-The thin or medium-sized patient is suitable for any of the

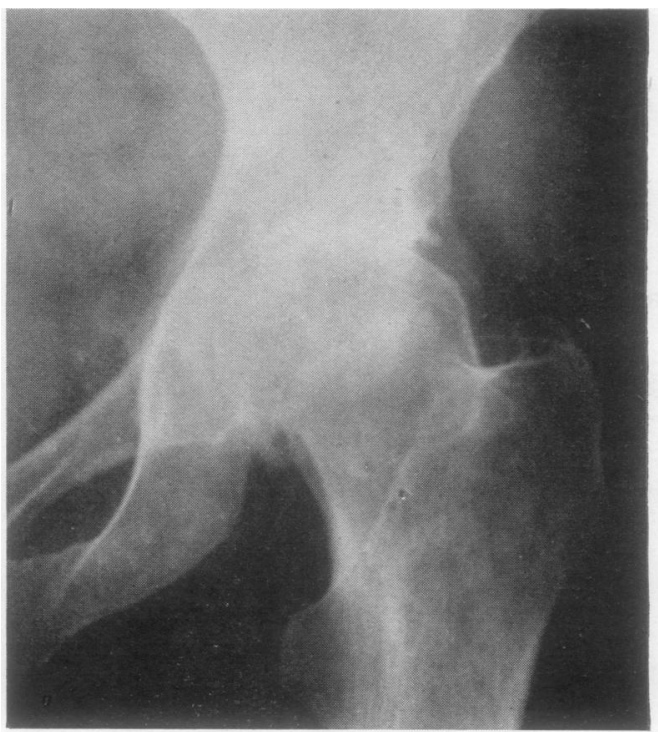

Fig. 3.- $X$ ray of left hip of female patient, aged 60 . Arthrodesis contraindicated by her occupation of chiropodist. operative procedures. The fat and overweight $\frac{2}{3}$ individual presents a much more difficult problem; although it is easy to see that the heavy patient may $\frac{0}{\omega}$. not do well with a Judet or vitallium cup because of $\vec{\Rightarrow}$ the mechanical strain on the hip, the shape of the $\stackrel{\oplus}{?}$ patient will sometimes contraindicate an arthrodesis, 을 because of the difficulties of nursing in a plaster. 음 A compromise solution for the fat patient is the $\frac{\sigma}{\bar{D}}$

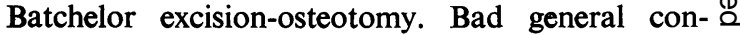
dition may contraindicate any operation, but every now and then a case turns up in which severe pain $\vec{O}$ in the hip, especially night pain, provides an overwhelming reason for operation in spite of old age or $\vec{\omega}$ severe medical disorder. It is surprising what can be done to get these patients fit for operation on the hip, by a preliminary period of "stabilization" in a $\vec{N}$ medical ward, although the patient with some $\omega$ failure of renal function is always in a dangerous $\vec{\bullet}$ position. The medically ill patient is never fit for $\infty$ arthrodesis, because of the long period in plaster, and one would then usually select a Judet operation.

A co-operative attitude in the patient is essential $\mathbb{D}$ before any operation can be decided upon. Sometimes he will refuse anything more drastic and $\frac{\mathbb{D}}{3}$ time-consuming than a denervation, and some $\underset{\mathbb{\Phi}}{\overrightarrow{0}}$ patients for whom an arthrodesis is indicated will steadfastly refuse the surgeon's reasoning and insie of on reconstruction and a mobile hip. In this matte the patient must make the final choice.

(3) Economic and Social Features.-There are certain points about the final result from the
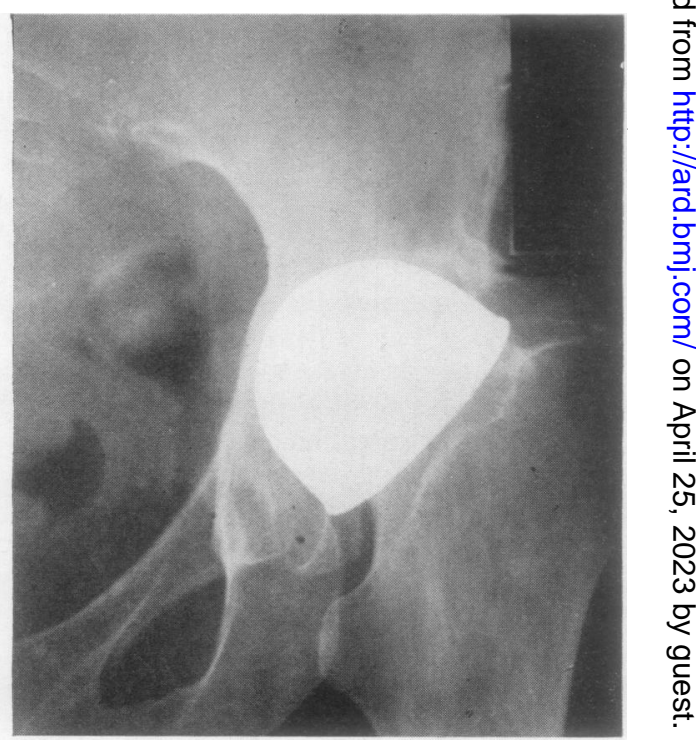

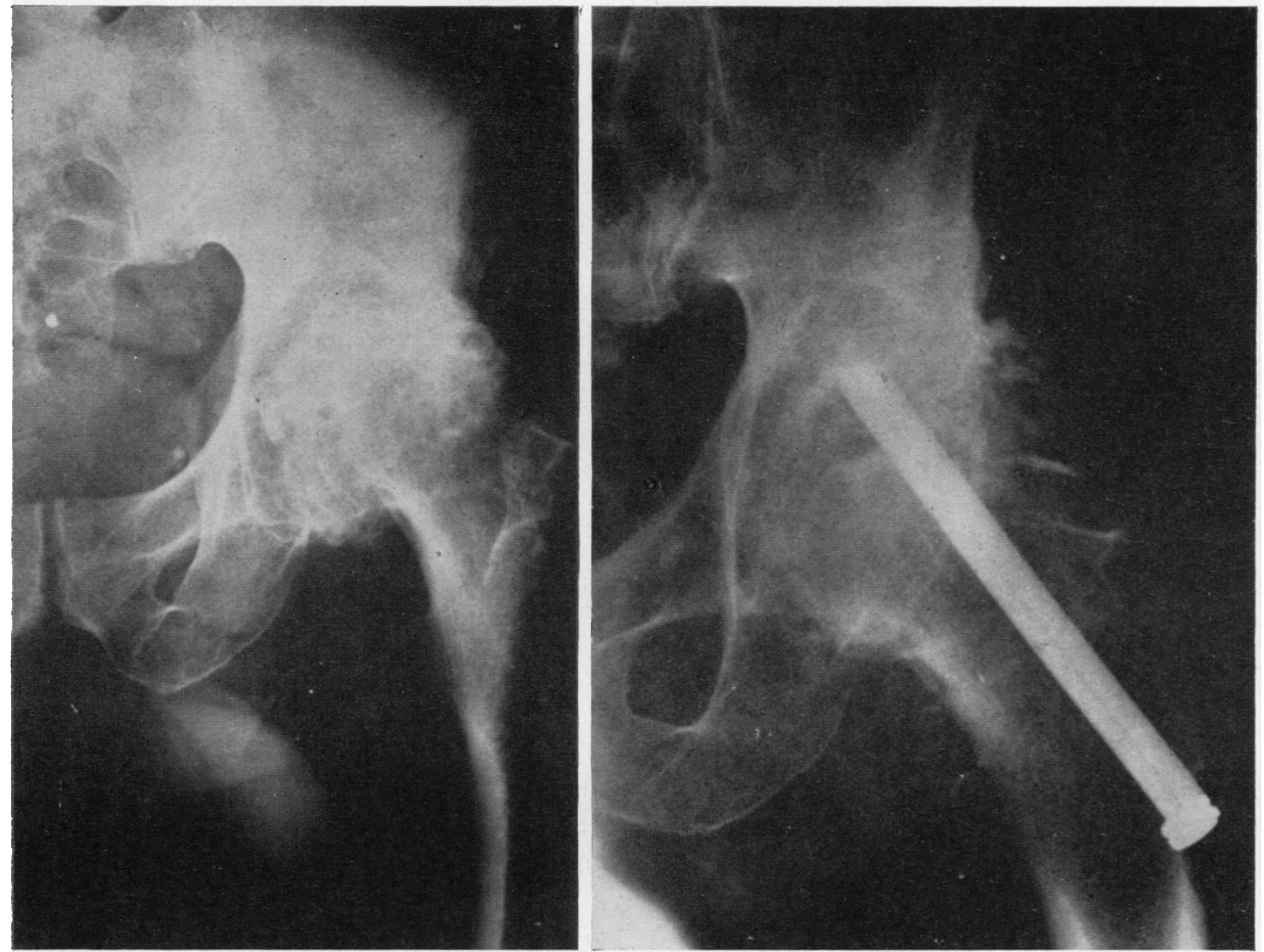

Fig. 4.-Unilateral osteo-arthritis of hip in a farmer, aged 60 . He was able to return to his full occupation, without pain, after arthrodesis by the Watson-Jones method.

economic and social point of view which we should consider. The patient with an arthrodesed hip finds it difficult to change quickly from a sitting to a standing position and he needs room to do it in. He will have difficulty in using steep or narrow staircases. Unless the knee bends well beyond a right angle, he will not be able to lace his own shoes. These points must be considered carefully in those who have to drive small cars, who wish to travel much in public transport, who live in tenements or flats without lifts, or who live alone (Fig. 3). After reconstruction, although the hip may be mobile and painless, the patient often cannot walk without a stick, he cannot stand for long, he will not be able to walk much, or work at all, on rough ground. The limp is usually rather more obvious than that after arthrodesis. The arthrodesed patient can stand for hours and walk long distances; he may disguise his limp surprisingly well, and can work successfully as a labourer or in agriculture (Fig. 4).

\section{(4) Type of Arthritis}

Osteo-Arthritis.-Local changes in the femur or acetabulum (for example, avascular necrosis, cystic degeneration, or the ctistortion of cox plana) may contraindicate a vitallium mould because of the carpentering difficulty of fitting reshaped head to acetabular cup. Unless the neck of the femur is impossibly short we can use a Judet head more favourably, because we can shape the head to take the base of the prosthesis or can fit a large Judet head on a comparatively narrow diameter neck. In some cases of severe disproportion or destruction we can fall back on the Batchelor operation with advantage. Gross avascular or cystic changes may sometimes contraindicate an ordinary arthrodesis, and we may decide for this reason to do a Brittain arthrodesis, or perhaps a reconstruction.

Rheumatoid Arthritis.-By the time the hip is involved, crippling from other joints is often so great 

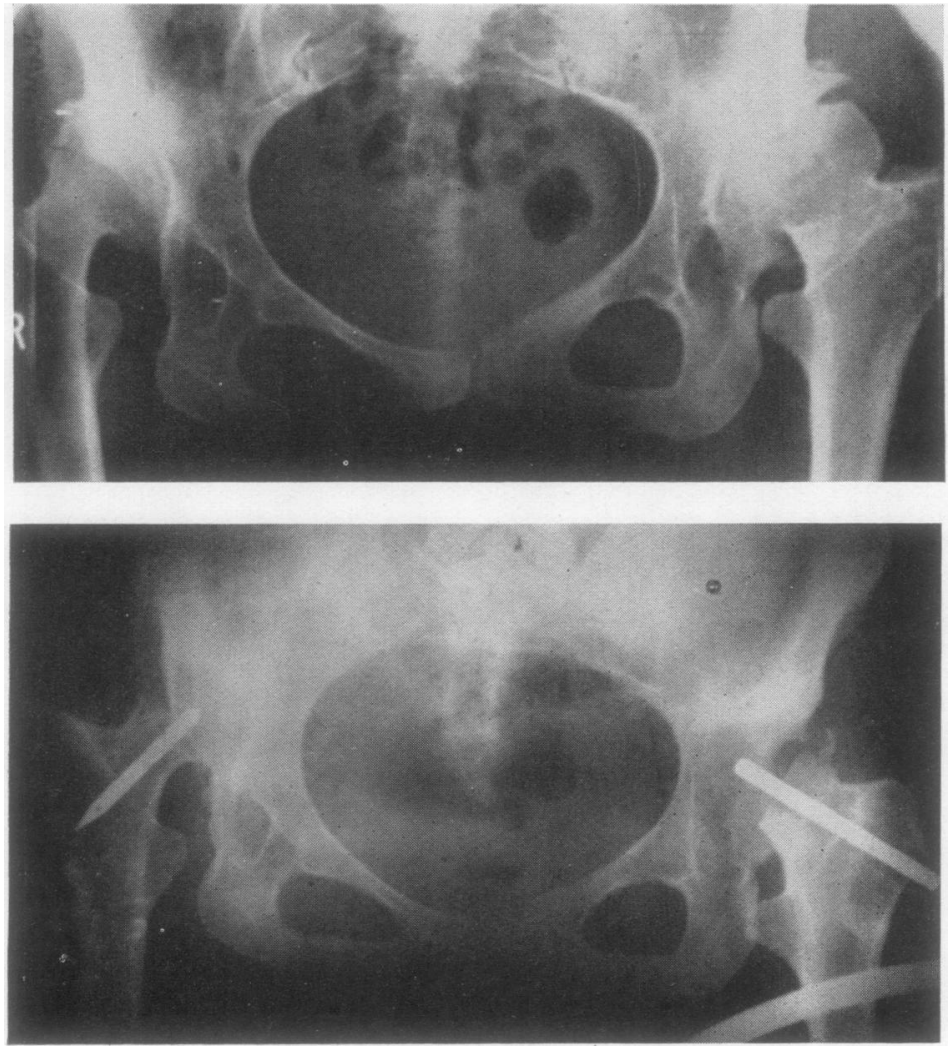

Fig. 5.-Judet reconstruction for bi-lateral congenital dislocation of both hips with painful osteo-arthritis.

that a severe operation on the hip would be unreasonable. There are, however, a few cases in which a reconstruction must be undertaken. Arthrodesis is ruled out by either a bilateral affection of the hips or stiffness of one or both knees or of the spine. The vitallium mould is probably better than the Judet head because of the difficulty of doing a revision operation after the acrylic head is in place. The Batchelor operation requires too much pelvic tilting and balance when the patient walks to be successful in the severely crippled, and in all these operations we must remember that the patient may be unable to use a stick or crutches because of the condition of the hands or elbows.

Ankylosing Spondylitis.-These are usually bilateral cases, and satisfactory results have been reported from all three methods of reconstruction. The Batchelor operation has advantages because after the first stage the hip is very mobile, severe deformity can be corrected, and atrophied muscles can be retrained and strengthened by the use of weight-balanced traction. When adequate movement, control, and power have been re $\frac{\mathbb{\Phi}}{5}$ gained, the patient is ready for the second stage.

Old Congenital Dislocation of the Hip.-Although secondary osteo $\stackrel{\text { ? }}{7}$ arthritic change is the cause of pain in middle age, the operative prob $\overline{\bar{\sigma}}$ lem is different because of gros: displacement and the false acetae bulum. The vitallium mould operaon tion is satisfactory when there is subluxation, but it is difficult to make a good mechanical joint wherw there is a real dislocation. The Judet operation is better (Fig. 5) No attempt is made to reduce the dislocation, but the false acetaes bulum is deepened to fit a large acrylic head. Arthrodesis rarelyo succeeds in these cases.

Summary

We can now summarize briefi|⿱亠丷厂心 the indications for advising one rather than another of these opera $₫$ tions.

ठ을

Arthrodesis.-This is suitable the young type of patientnecessarily young in years-witlp unilateral arthritis, who wishes te use his or her hip hard. The knee joint must be mobile, and the spine reasonably? supple. Almost invariably the affection will be osteo음 arthritis, and more often than not of the secondary type. Obesity may contraindicate arthrodesis.

Reconstruction.-This is to be used if both hips arê affected, or one or both knees, or if the back is stiff, or if social or economic conditions demand 2 . mobile hip. It is suitable for the rather ill patient, the fat patient who will not stand incarceration in bed or plaster, or the patient who, in spite of sound arguments, will not agree to arthrodesis.

For those cases in which local changes at the hip suggest that neither the vitallium mould nor the acrylic head would be mechanically suitable, the Batchelor operation provides an alternative. This operation is also useful for the very heavy patient $t_{\mathfrak{W}}^{N}$ and for one in whom muscular re-development is more than usually necessary but cannot be achieved before operation.

We must wait some years before deciding whether? the Smith-Petersen or the Judet is the better opera-0 
tion. At present the acrylic head is more popular, except for rheumatoid patients.

Denervation.-For the patient with a mobile hip, no deformity, and pain localized in the groin, this operation will probably relieve pain, but only temporarily.

In conclusion, it is well to remember the words of Gade (1947):

It is almost 87 years since the first case of osteoarthritis of the hip was treated operatively-a very long period in the history of surgery-and yet it is hardly wrong to say that this branch of surgery is still in the experimental stage. A comparison of what has been achieved with the many problems still unsolved gives a decided impression of how difficult it has been for surgery to conquer this field of pathology in spite of the fact that surgery has no serious competitors.

\section{REFERENCES}

Albee, F. H. (1908). J. Amer. med. Ass., 50, 1977.

(1921). Amer. J. Surg., 35, 296.

Batchelor, J. S. (1945). Froc. roy. Soc. Med., 38, 689.

- (1948). Postgrad. med. J., 24, 241.

Brittain, H. A. (1942). "Architectural Principles in Arthrodesis". Livingstone, Edinburgh.

Donkersloot, T. A. (1947). Ned. T. Geneesk., 91, 3674.

Elmslie, R. C. (1923). Brit. med. J., 2, 1206.

Fock, C. (1861). Arch. klin. Chir., 1, 172.

Gade, H. G. (1947). Acta chir. scand., 95, Suppl. 120

Girdlestone, G. R. (1945). Proc. roy. Soc. Med., 38, 363.

Hoffa, A. (1906). Z. Orthop., 17, 1.

Judet, J., and Judet, R. (1950). J. Bone Jt Surg., 32B, 166.

Judet, R., and Judet, J. (1952). Ibid., 34B, 173.

Kaplan, E. B. (1948). Ibid., 30A, 213.

Kawlan, E. B. (1948). Ibid., 30A,

Law, W. A. (1948). Ibid., 30B, 76.

Mulder, J. D. (1948). J. Bone Jt Surg., 30B, 446.

Murphy, J. B. (1905). J. Amer. med. Ass., 44, 1573, 1671, and 1749.

Obletz, B. E., Lockie, L. M., Milch, E., and Hyman, I. (1949). J. Bone Jt Surg., 31A, 805.

Platt, H., and 16 others (1922). Ibid., 4, 144

Pridie, K. H. (1945). Proc. roy. Soc. Med., 38, 363

Smith-Petersen, M. N. (1936). J. Bone Jt Surg., 18, 869.

(1939). Ibid., 21, 269.

Tavernier, L. (1944). Lyon chir., 39, 649.

-, and Godinot, C. (1945). "Traitement chirurgical de l'arthrite sèche de la hanche". Masson, Paris.

-, and Truchet, P. (1942). Rev. Orthop., 28, 62-68.

Watson-Jones, R. (1935). J. Bone Jt Surg., 17, 239.

(1945). Proc. roy. Soc. Med., 38, 363 .

\section{Choix de l'opération dans l'arthrite chronique de la hanche}

\section{RÉSUMÉ}

Nous pouvons maintenant résumer brèvement les indications qui nous font préconiser une opération plutôt qu'une autre.

Arthrodèse.-Celle-ci convient au type jeune-pas nécessairement en années-avec une arthrite unilatérale qui voudrait se servir de sa hanche. Il faudra que l'articulation du genou soit mobile et que l'épine soit assez souple. Presque invariablement il s'agira d'une ostéoarthrite, assez souvent de type secondaire. L'obésité peut contre-indiquer une arthrodèse.

Reconstruction.-Cette opération est recommandée lorsque les deux hanches sont atteintes, ou bien un ou deux genoux sont affectés, ou le dos est rigide, ou les conditions économiques ou sociales exigent une hanche mobile. Elle convient au malade pas trop robuste, à l'obèse qui ne pourra pas supporter l'alitement ou l'emplâtre ou à celui qui ne veut pas entendre raison et refuse l'arthrodèse.

Pour les cas où les lésions locales de la hanche suggèrent que ni un moule de vitellium ni une tête acrylique ne seraient appropriés du point de vue mécanique, l'opération de Batchelor offre l'alternative. Cette opération convient aussi au très gros malade ainsi qu'à celui chez qui le redeveloppement musculaire est particulièrement necessaire et qui ne peut pas l'obtenir avant l'opération.

Il faudra attendre plusieurs années pour décider si l'opération de Smith-Peterson ou bien celle de Judet est la meilleure. Pour le moment la tête acrylique est plus en vogue, sauf chez les rhumatisants.

Enervation.-Chez le malade dont la hanche est mobile, sans deformation et avec la douleur localisée à l'aine, cette opération procurera un soulagement, quoique temporaire, de la douleur.

\section{Escogimiento de la operación en la artritis crónica de la cadera \\ SUMARIO}

Podemos ahora resumir brevemente las indicaciones que nos hacen aconsejar el procedimiento operatorio particular.

Artrodesis conviene al tipo joven-no siempre en años de vida - con una artritis unilateral que desea servirse de su cadera. La articulación de la rodilla ha de ser móvil y la espina bastante flexible. Casi invariablemente se tratará de una ósteoartritis, a menudo del tipo secundario. La obesidad puede contra-indicar la artrodesis.

Reconstrucción se recomenda en casos de afección bilateral de las articulaciones de la cadera o de la rodilla, de rigidez dorsal, o cuando las condiciones sociales o económicas exigen una cadera móvil. Esta operación conviene al paciente enfermizo, al gordo que no podrá endurar la incarceración en la cama o en el yeso y al que, a pesar de buen consejo, rehusa la artrodesis.

Para los casos de lesiones locales de la cadera sugeriendo que tanto un molde de vitellium como una cabeza acrílica no convienen desde el punto de vista mecánico, la operación de Batchelor ofrece la alternativa. Esta operación conviene también al enfermo muy gordo así como al que precisa particularmente de rehabilitación muscular sin poder conseguirla antes de la operación.

Habrá que esperar varios años para poder decidir si la operación de Smith-Peterson o la de Judet est la mejor. Hoy la cabeza acrílica es más en boga, salvo en los reumáticos.

Denervación.-En el enfermo cuya cadera es móvil, sin deformación y con el dolor localizado en la ingle, esta operación traerá alivio, aunque temporario, del dolor. 